Asian J. Med. Biol. Res. 2017, 3 (4), 499-503; doi: 10.3329/ajmbr.v3i4.35341

\author{
Asian Journal of \\ Medical and Biological Research \\ ISSN 2411-4472 (Print) 2412-5571 (Online) \\ www.ebupress.com/journal/ajmbr
}

\title{
Article \\ Study on growth traits at weaning and yearling stages of indigenous and F1 crossbred buffalo in Bangladesh
}

Md. Shahjahan*, Asma Khatun, Sumya Khatun, Md. Mahbubul Hoque, Sohrab Hossain, Quazi M Emdadul Huque, Tabith M Awal and Abdul Awal Mintoo

Lal Teer Livestock Limited, Anchor Tower, 108, Bir Uttam C. R. Dutta Road, Dhaka 1205, Bangladesh

*Corresponding author: Dr. Md. Shahjahan, Bangladesh Livestock Research Institute (BLRI), Regional Station, Baghabari, Shahjadpur, Sirajganj-6770, Bangladesh. E-mail: sajubau@gmail.com

Received: 07 December 2017/Accepted: 21 December 2017/ Published: 28 December 2017

\begin{abstract}
This study was planned to clarify the variation of body weight and average daily gain traits in both indigenous and F1 crossbreed (Local $\times$ Mediterranean) buffalo at weaning (sixth month) and yearling stages (twelfth month). Data were collected from 33 indigenous and $35 \mathrm{~F} 1$ crossbred buffalo progeny during the period of 2011 to 2014 with intensive management system at Research and Development farm of Lal Teer Livestock Limited in Bangladesh. The gathered data were analyzed using general linear model (GLM) and independent sample $t$ test. The effect of parity, sex, season and breeding year on body weight and average daily gain were observed where significant values found in breeding period $(p<0.01)$ of crossbred buffalo for body weight. It might be the reason of crossbreeding to indigenous buffalo cows using imported semen with better genetic merit. The parity $(p<0.05)$, season $(p<0.05)$ and breeding period $(p<0.01)$ were also significant for average daily gain measurement which suggesting environmental adaptability beside additive genetic effects. Body weights were measured at weaning and yearling stages for both local (113 to $195 \mathrm{~kg}$ ) and F1 crossbred (144 to $220 \mathrm{~kg}$ ) buffalo progeny to screen the elite offspring for the Genetic Farm and Bull station. Similarly, average daily gain observed 469 to $457 \mathrm{~g}$ and 600 to $506 \mathrm{~g}$ at the previously mentioned two stages for both local and F1 buffalos, respectively. It was observed that studied traits were comparatively better in F1 buffalo progeny than indigenous. The comparison of average daily weight gains between indigenous and F1 buffalos at weaning and yearling periods showed significant differences for body weight $(p<0.001)$ and average daily gain $(p<0.05)$, respectively. It is concluded that genetic gain might be possible in local buffalo population by grading up process which could switch the traditional buffalo rearing to commercial level as well as meeting the nutritional demand of country people.
\end{abstract}

Keywords: local; body weight; daily gain; meat production; comparative study

\section{Introduction}

Buffalo production is not very frequent in Bangladesh because of its lower acceptance to the people due to least milk production and rearing or management difficulties compare to cattle. Huque and Borghese (2012) reported that $96.40 \%$ buffalos of the world are available in Asia. Based on the report of DLS (2015) about 1.64 million buffalo are existed in Bangladesh of which $40 \%$ are found in the coastal regions (Faruque et al., 1990). Hasnath (1985) observed that average live weight of buffalo was $320 \mathrm{~kg}$ with $44 \%$ dressing percentage. In last five years, meat production trend increased from 1.28 MT to 5.86 MT in Bangladesh which simultaneously reduced daily supply gap from $98 \mathrm{~g}$ to $17 \mathrm{~g}$ per day according to standard requirement $(120 \mathrm{~g} / \mathrm{day})$ for an adult (DLS, 2011 and 2015).

In-depth studies on buffalo growth traits are scanty in Bangladesh. Therefore, this study was aimed to reveal the differences between indigenous and crossbred buffalo progenies regarding body weight and average daily gain 
at weaning and yearling stages so that clarification could be found on buffalo production concerning commercial farming.

\section{Materials and Methods}

Data on body weight (BW) and average daily gain (ADG) at sixth and twelfth months were collected including pedigree records from 33 indigenous and 35 F1 crossbred (Indigenous $\times$ Mediterranean) buffalo progeny at the first private livestock research farm of Bangladesh (Lal Teer Livestock Limited) during the period of 2011 to 2014. All the progeny and their dams were reared under same management system in high input system. Data were analyzed following general linear model (GLM) procedure using the statistical analysis system (SAS) version 9.1.3 (SAS Institute Inc., Cary, NC, USA) including independent sample $t$ test. The descriptive statistics and mean separation were calculated using statistical package for the social sciences (SPSS) version 16.0 (SPSS Inc., Chicago, IL, USA) with Tukey's HSD mean separation post hoc test.

\section{Results and Discussion}

\subsection{Body weight of buffalo progeny at weaning and yearling stages}

The effect of parity, sex, season and breeding year were studied (Table 1) where only breeding period showed significant $(p<0.01$ ) differences in crossbred buffalos for body weight at both

weaning and yearling periods. It might be the reason of artificial insemination to indigenous buffalos with different categories of semen having distinct genetic merits. Body weight variation (Figure 1) and comparative study (Figure 2) of those traits in both indigenous and crossbred buffaloes showed significant differences in both weaning $(p<0.001)$ and yearling $(p<0.05)$ stages.

In Egyptian buffalo progeny (Shahin et al., 2010) the average body weights at six and twelve months were recorded as 114 and $179 \mathrm{~kg}$, respectively. These results agreed with our findings for local buffalo. The weaning $(66 \mathrm{~kg})$ and yearling $(146 \mathrm{~kg})$ weights were much lower than our findings either in crossbred and native progeny (Pandya et al., 2015) which indicating the effect of breed with better management in stall feeding. The study of Zaba and Clevañer (2001) and Rodas-González et al. (2001) found 201 and $235 \mathrm{~kg}$ of weaning weight in buffalo progeny of Argentina and Venezuela, respectively. These results were much higher than our findings either in local and F1 crossbred; that could be the result of a beef breeding programme while planned breeding strategy of this study has focused on developing a dual purpose buffalo breed.

Table 1. Effect of different factors for body weight in weaning and yearling stages of Indigenous and Crossbred (Indigenous $\times$ Mediterranean) buffalo populations.

\begin{tabular}{|c|c|c|c|c|c|c|c|}
\hline \multirow[t]{3}{*}{ Factor } & \multirow[t]{3}{*}{ Category } & \multirow[t]{3}{*}{$\mathbf{n}$} & \multirow{2}{*}{\multicolumn{2}{|c|}{$\begin{array}{l}\text { Indigenous } \\
\text { Mean } \pm \text { SE }\end{array}$}} & \multirow[t]{3}{*}{$\mathbf{n}$} & \multirow{2}{*}{\multicolumn{2}{|c|}{$\begin{array}{c}\text { Indigenous } \times \text { Mediterranean } \\
\text { Mean } \pm \text { SE }\end{array}$}} \\
\hline & & & & & & & \\
\hline & & & $\mathrm{BW}_{6}$ & $\mathrm{BW}_{12}$ & & BW $_{6}$ & $\mathbf{B W}_{12}$ \\
\hline \multirow[t]{2}{*}{ Parity } & Second & 19 & $118.53 \pm 5.40$ & $188.26 \pm 8.88$ & 28 & $145.93 \pm 4.71$ & $220.50 \pm 6.85$ \\
\hline & Third & 14 & $106.50 \pm 7.40$ & $203.86 \pm 19.25$ & 7 & $137.00 \pm 8.07$ & $216.50 \pm 17.28$ \\
\hline$P$ value & & & 0.075 & 0.212 & & 0.711 & 0.530 \\
\hline \multirow[t]{2}{*}{ Sex } & Male & 18 & $119.56 \pm 6.81$ & $206.56 \pm 13.11$ & 19 & $144.26 \pm 4.58$ & $212.53 \pm 6.64$ \\
\hline & Female & 15 & $106.07 \pm 5.11$ & $180.87 \pm 13.52$ & 16 & $144.00 \pm 7.30$ & $217.53 \pm 11.70$ \\
\hline Pvalue & & & 0.698 & 0.929 & & 0.777 & 0.595 \\
\hline \multirow[t]{3}{*}{ Season } & Summer & 10 & $99.60 \pm 7.06$ & $161.70 \pm 10.87$ & 7 & $142.85 \pm 6.93$ & $219.43 \pm 7.03$ \\
\hline & Rainy & 10 & $110.50 \pm 5.48$ & $184.70 \pm 16.13$ & 23 & $146.09 \pm 5.52$ & $222.28 \pm 9.41$ \\
\hline & Winter & 13 & $126.31 \pm 7.93$ & $228.23 \pm 15.15$ & 5 & $137.00 \pm 10.48$ & $219.70 \pm 4.33$ \\
\hline P value & & & 0.060 & 0.108 & & 0.592 & 0.548 \\
\hline \multirow[t]{4}{*}{ Year } & 2011 & 13 & $105.54 \pm 7.94$ & $197.08 \pm 19.46$ & & - & - \\
\hline & 2012 & 4 & $148.50 \pm 11.82$ & $241.00 \pm 18.81$ & 12 & $166.75^{\mathrm{a}} \pm 6.36$ & $252.42^{\mathrm{a}} \pm 11.00$ \\
\hline & 2013 & 7 & $119.29 \pm 7.31$ & $201.29 \pm 17.53$ & 17 & $135.29^{\mathrm{b}} \pm 3.63$ & $202.44^{b} \pm 6.72$ \\
\hline & 2014 & 9 & $104.67 \pm 3.20$ & $166.22 \pm 7.36$ & 6 & $124.00^{c} \pm 6.19$ & $203.17^{\mathrm{b}} \pm 2.91$ \\
\hline Pvalue & & & 0.417 & 0.337 & & 0.005 & 0.019 \\
\hline Overall & & 33 & $113.42 \pm 4.47$ & $194.88 \pm 9.55$ & 35 & $144.14 \pm 4.10$ & $219.70 \pm 6.36$ \\
\hline
\end{tabular}


Table 2 Effect of different factors for average daily gain in weaning and yearling stages of Indigenous and Crossbred (Indigenous $\times$ Mediterranean) buffalo populations.

\begin{tabular}{|c|c|c|c|c|c|c|c|}
\hline \multirow[t]{3}{*}{ Factor } & \multirow[t]{3}{*}{ Category } & \multirow[t]{3}{*}{$\mathbf{n}$} & \multirow{2}{*}{\multicolumn{2}{|c|}{$\begin{array}{c}\text { Indigenous } \\
\text { Mean } \pm \text { SE }\end{array}$}} & \multirow[t]{3}{*}{$\mathbf{n}$} & \multirow{2}{*}{\multicolumn{2}{|c|}{$\begin{array}{c}\text { Indigenous } \times \text { Mediterranean } \\
\text { Mean } \pm \text { SE }\end{array}$}} \\
\hline & & & & & & & \\
\hline & & & $\mathbf{A D G}_{0-6}$ & $\mathbf{A D G}_{0-12}$ & & $\mathbf{A D G}_{0-6}$ & $\mathbf{A D G}_{0-12}$ \\
\hline \multirow[t]{2}{*}{ Parity } & Second & 19 & $488.16 \pm 28.62$ & $434.21 \pm 24.72$ & 28 & $609.50 \pm 25.78$ & $508.29 \pm 18.41$ \\
\hline & Third & 14 & $442.86 \pm 33.21$ & $487.57 \pm 50.56$ & 7 & $560.29 \pm 41.12$ & $497.29 \pm 43.54$ \\
\hline$P$ value & & & 0.040 & 0.162 & & 0.870 & 0.458 \\
\hline \multirow[t]{2}{*}{ Sex } & Male & 18 & $500.28 \pm 32.77$ & $487.50 \pm 35.08$ & 19 & $597.37 \pm 24.89$ & $509.58 \pm 16.77$ \\
\hline & Female & 15 & $431.33 \pm 24.86$ & $420.07 \pm 36.73$ & 16 & $602.38 \pm 39.52$ & $501.94 \pm 31.62$ \\
\hline$P$ value & & & 0.664 & 0.910 & & 0.794 & 0.593 \\
\hline \multirow[t]{3}{*}{ Season } & Summer & 10 & $397.80^{b} \pm 33.14$ & $368.50 \pm 27.67$ & 7 & $587.43 \pm 32.50$ & $502.71 \pm 17.78$ \\
\hline & Rainy & 10 & $447.50^{\mathrm{ab}} \pm 30.79$ & $426.30 \pm 46.00$ & 23 & $612.35 \pm 29.51$ & $514.22 \pm 24.91$ \\
\hline & Winter & 13 & $540.15^{\mathrm{a}} \pm 35.09$ & $548.31 \pm 39.36$ & 5 & $558.40 \pm 66.59$ & $473.40 \pm 11.10$ \\
\hline$P$ value & & & 0.020 & 0.109 & & 0.598 & 0.483 \\
\hline \multirow[t]{4}{*}{ Year } & 2011 & 13 & $437.77 \pm 35.45$ & $469.00 \pm 50.79$ & - & - & - \\
\hline & 2012 & 4 & $656.50 \pm 57.16$ & $580.75 \pm 55.06$ & 12 & $717.58^{\mathrm{a}} \pm 35.04$ & $592.58^{\mathrm{a}} \pm 29.08$ \\
\hline & 2013 & 7 & $487.00 \pm 36.63$ & $467.14 \pm 48.99$ & 17 & $554.76^{\mathrm{b}} \pm 19.55$ & $460.71^{\mathrm{b}} \pm 17.91$ \\
\hline & 2014 & 9 & $416.56 \pm 18.78$ & $376.22 \pm 22.04$ & 6 & $491.00^{\mathrm{b}} \pm 40.33$ & $461.67^{\mathrm{b}} \pm 5.91$ \\
\hline$P$ value & & & 0.118 & 0.270 & & 0.008 & 0.020 \\
\hline Overall & & 33 & $468.94 \pm 21.70$ & $456.85 \pm 25.69$ & 35 & $599.66 \pm 22.21$ & $506.09 \pm 16.82$ \\
\hline
\end{tabular}

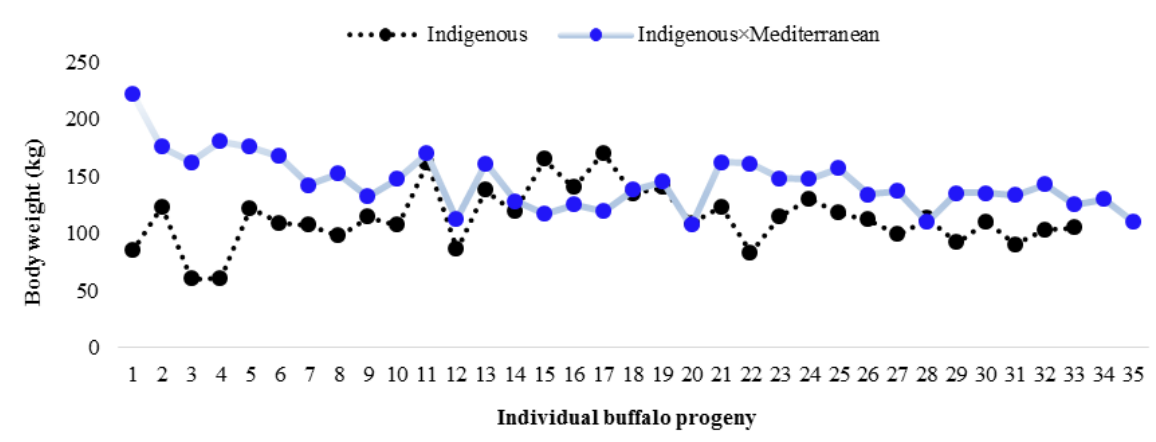

Figure 1. Diversity in body weight (kg) of indigenous and crossbred buffalo progeny.

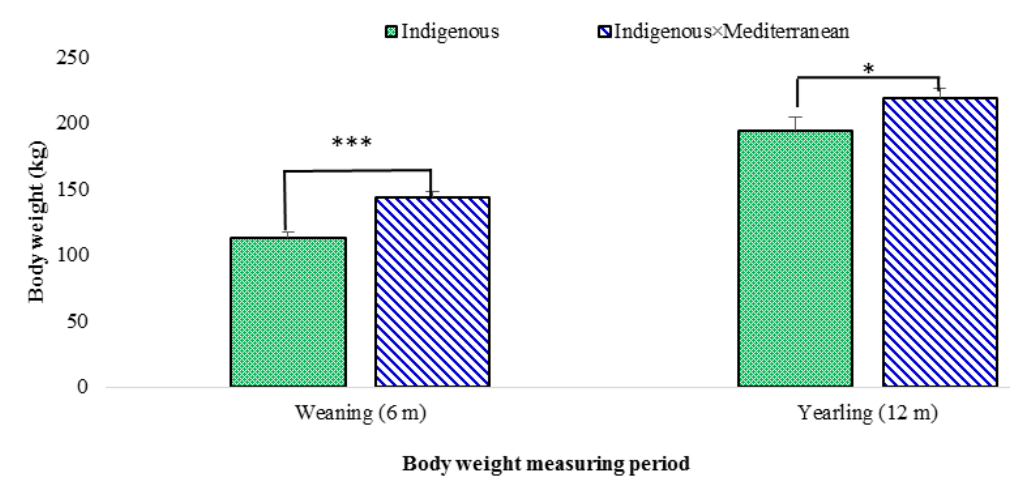

Figure 2. Difference in body weight (kg) between indigenous and crossbred buffalo progeny at weaning and yearling stages. 


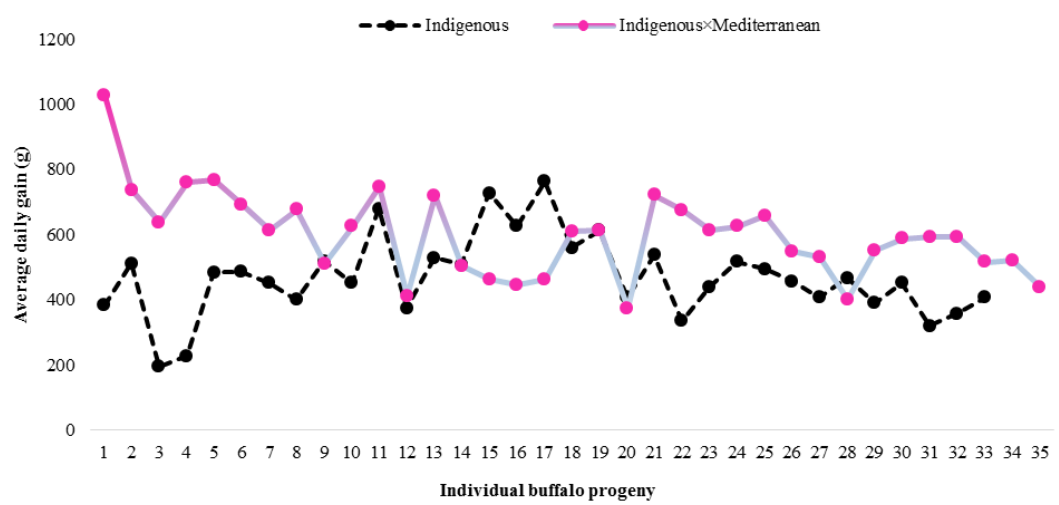

Figure 3. Diversity in average weight gain (g) between indigenous and crossbred progeny.

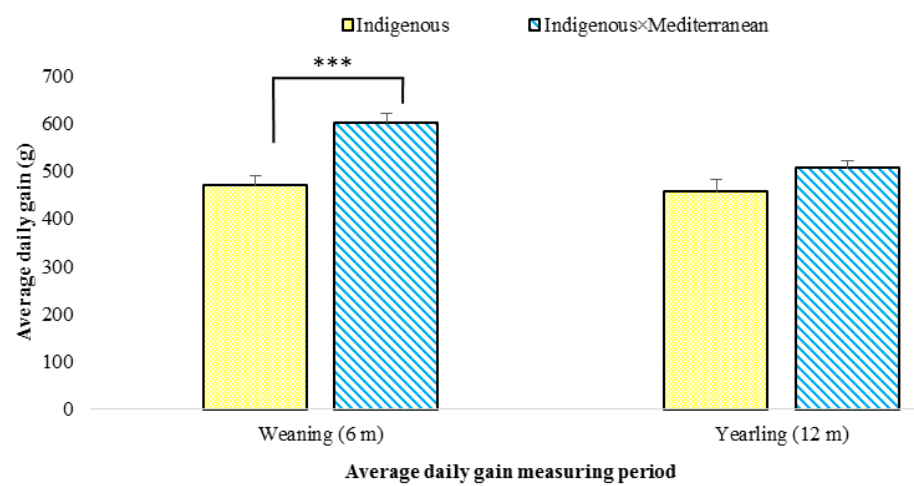

Figure 4. Difference in body weight (kg) between indigenous and crossbred buffalo progeny.

\subsection{Average body weight gain of buffalo progeny at weaning and yearling stages}

Out of four factors, significant variation observed in parity $(p<0.05)$ and season $(p<0.05)$ for indigenous during weaning period (Table 2). Similarly, differences also found in the breeding period $(p<0.01)$ of crossbred progeny at both periods. These findings also indicated the superiority of crossbred progeny (Figure 3 and 4) regarding average daily gain than indigenous buffalo progeny.

The pre-weaning and post-weaning growth rate of Nili-Ravi buffalo progeny were 316 and $301 \mathrm{~g} /$ day in Pakistan but those were much lower than our observed growth rate in both local and crossed buffalo progeny (Akhter et al., 2012) which might be the result of breed and management variations. But slightly agreed with the findings of Shahin et al. (2010) mentioning 490 and $380 \mathrm{~g}$ for the mentioned periods in Egyptian local buffalo progenies. The significant difference of daily average growth rate in different years reflected the superiority of semen used in AI including slightly variation in the level of management, availability of good quality feed, temperature and humidity. Body weight gain of animals after weaning is a substantial feature for growth evaluation which is not only limited within breed, sex, nutrition etc. (Alves and Franzolin, 2015).

\section{Conclusions}

It is concluded that F1 crossbred buffalo progeny were superior to local buffalo regarding the traits of body weight and average daily gain. Although parity and seasonal effects influenced the growth traits of local progeny the superiority of sire in a specific period enhanced the growth traits in crossbred. As a thinking of higher or commercial buffalo meat production, systemic crossbreeding by Mediterranean with native buffalo has a bright prospect in Bangladesh.

\section{Conflict of interest}

None to declare.

\section{Acknowledgements}

The authors are grateful to the Private Sector Investment programme (PSI) of Netherlands for the funding of this study under the project of "Cattle \& Buffalo Improvement in Bangladesh (PSI11/BD/23)". 


\section{References}

Akhtar P, U Kalsoom, S Ali, M Yaqoob, K Javed, ME Babar, MI Mustafa and JI Sultan, 2012. Genetic and phenotypic parameters for growth traits of Nili-Ravi buffalo heifers in Pakistan. J. Anim. Plant Sci., 22: 347352.

Alves TC and R Franzolin, 2015. Growth curve of buffalo grazing on a grass pasture. R. Bras. Zootec., 44: 321326.

DLS 2011. General information related to livestock. Directorate of Livestock Services, Monthly Fisheries and Livestock Bulletin, Ministry of Fisheries and Livestock, Government of Republic Bangladesh, Khamarbari, Farmgate, Dhaka, Bangladesh.

DLS 2015. Annual report of Department of Livestock Service. Ministry of Fisheries and Livestock, Government of Republic Bangladesh, Khamarbari, Farmgate, Dhaka, Bangladesh.

Faruque MO, MA Hasnath and NU Siddique, 1990. Present status of buffaloes and their productivity. AsianAustralas J. Anim. Sci., 3: 287-292.

Hasnath MA, 1985. Breeding, feeding and management of water buffalo in Bangladesh. Proceedings of the $3^{\text {rd }}$ AAAP Animal Science Congress, Tokyo, Japan, pp.70-79.

Huque QME and A Borghese, 2012. Status and perspectives of buffalo in Bangladesh. Buff. Bul., 32: 11791183.

Pandya GM, CG Joshi, DN Rank, VB Kharadi, BP Bramkshtri, PH Vataliya and JV Solanki, 2015. Genetic analysis of body weight traits of Surti buffalo. Buff. Bul., 34: 189-195.

Rodas-Gonzalez A, N Huerta-Leidens, A Vidal, RY Rodriguezand O Colina, 2001. Rendimientocarnicero de búfalos vs. vacunosacebuadosproducidos a sabanas y sacrificadosserialmente a cuatroedadescontemporáneas. Proceedings of the 5th World Buffalo Congress, Maracaibo, Venezuela, pp.65-69.

Shahin KA, OY Abdallah, TA Foodaand KA Mourad, 2010. Selection indexes for genetic improvement of yearling weight in Egyptian buffaloes. Arch.fur Tierz., 53: 436-446.

Zaba MY and F Clevañer, 2001. Cría de búfalosen Argentina. Proceedings of the 6th World Buffalo Congress, Maracaibo, Venezuela, pp.705-717. 